20 Patel C. Reduction of serum cholesterol and blood pressure in hypertensive patients by behavior modification. $f R$ Coll Gen Pract 1976; $26: 211-5$.

21 Johnson WP, Grover JA. Hemodynamic and metabolic effects of physical training in four patients with essential hypertension. Can Med Assoc $\mathcal{F}$ $1967 ; 96: 842-6$

${ }^{22}$ Boyer JL, Kasch FW. Exercise therapy in hypertensive men. $\mathcal{J} A M A$ $1970 ; 221: 1668-71$

${ }^{23}$ Choquette G, Ferguson RJ. Blood pressure reduction in "borderline" hypertensives following physical training. Can Med Assoc $\mathcal{f}$ 1973; $108: 699-703$

24 Parijs J, Joossens JV,Van der Linden L, et al. Moderate sodium restriction and diuretics in the treatment of hypertension. Am Heart $\mathcal{f} 1973 ; 85$ : 22-34.

${ }^{25}$ Morgan T, Adams W, Gillies A, et al. Hypertension treated by salt restriction. Lancet $1978 ; \mathrm{i}: 227-30$.

${ }^{26}$ Morgan TO, Myers JB. Hypertension treated by sodium restriction. Med F Aust 1981 ;ii:396-7.

27 Lindner PG, Blackburn GL. Multidisciplinary approach to obesity utilizing fasting modified by protein-sparing diet. Obesity and Bariatric Medicine 1976;5:198-216.

${ }^{28}$ Reisin E, Abel R, Modan M, Siverberg DS, Eliahou HE, Modan B. Effect of weight loss without salt restriction on the reduction of blood pressure in overweight hypertensive patients. N Engl f Med 1978; 298: $1-6$.

29 Tuck ML, Sowers J, Dornfield L, Kledzik G, Maxwell M. The effect of weight reduction on blood pressure, plasma renin activity, and plasma aldosterone levels in obese patients. N Engl f Med 1981;304: 930-3.

${ }^{30}$ Goldring W, Chasis H, Schreiner GF, Smith HW. Reassurance in the management of benign hypertensive disease. Circulation 1956,14:260-4.

31 Frankel BL, Patel DJ, Horwitz D, et al. Treatment of hypertension with biofeedback and relaxation techniques. Psychosom Med 1978;40:276-93.

32 Benson H, Shapiro D, Tursky B, Schwartz G. Decreased systolic blood pressure through operant conditioning techniques in patients with essential hypertension. Science 1971;173:740-2.

${ }^{33}$ Elder ST, Ruiz ZR, Deabler HL, Dillenkoffer RL. Instrumental conditioning of diastolic blood pressure in essential hypertensive patients. f Appl Behav Anal 1973;6:377-82.

${ }^{34}$ Elder ST, Eustis NK. Instrumental blood pressure conditioning in out-patient hypertensives. Behav Res Ther 1975;13:185-8.

35 Goldman H, Kleinman KM, Snow MY, et al. Relationship between essential hypertension and cognitive functioning: effects of biofeedback. Psychophysiology 1975;12:569-73.
${ }^{36}$ Kristt DA, Engel BT. Learned control of blood pressure in patients with high blood pressure. Circulation 1975;51:370-8.

${ }^{37}$ Kleinman K, Goldman H, Snow MY, Koral B. Relationship between essential hypertension and cognitive functioning. II Effects of biofeedback training generalize to non-laboratory environment. Psychophysiology 1977;14:192-7.

${ }^{38}$ Benson H, Rosner BA, Marzetta BR, Klemchuk HM. Decreased blood pressure in pharmacologically treated hypertensive patients who regularly elicited the relaxation response. Lancet $1974 ; \mathrm{i}: 289-91$.

${ }^{39}$ Benson H, Rosner BA, Marzetta BR, Klemchuk HP. Decreased blood pressure in borderline hypertensive subjects who practised meditation. 7 Chronic Dis 1974;27:163-9.

${ }^{40}$ Blackwell B, Bloomfield S, Gartside P. Transcendental meditation in hypertension. Lancet 1976;i:223-6.

41 Stone RA, De Leo J. Psychotherapeutic control of hypertension. N Engl f Med 1976;294:80-4.

4. Pollack AA, Weber MA, Case DB, Laragh JH. Limitations of transcendental meditation in the treatment of essential hypertension. Lancet 1977; : 71-3.

${ }^{43}$ Seer P, Raeburn JM. Meditation training and essential hypertension: a methodological study. F Behav Med 1980;3:59-72.

44 Laughlin KD, Fisher L, Sherrard DJ. Blood pressure reductions during self-recording of home blood pressure. Am Heart f 1979;98:629-34.

${ }^{45}$ Raskin M, Bali LR, Peeke HV. Muscle biofeedback and transcendental meditation. A controlled evaluation of efficacy in the treatment of chronic anxiety. Arch Gen Psychiatry 1980;37:93-7.

${ }^{46}$ Agras WS, Taylor CB, Kraemer HC, Allen RA, Schneider JA. Relaxation training. Twenty four hour blood pressure reductions. Arch Gen Psychiatry 1980;37:859-63.

${ }^{47}$ Lovell RHH, chairman. Mild hypertension: the pressure to treat. The proceedings of a symposium by satellite. South Granville: Merck Sharp and Dohme (Australia) Ltd, 1981.

${ }^{48}$ Stuart RB. Behavioral control of overeating. Behav Res Ther 1967;5: 357-65.

49 Stuart RB, Davis B. Slim chance in a fat world: behavioral control of obesity. Illinois: Research Press, 1972.

${ }^{50}$ Ferguson JM, Marquis JN, Taylor CB. A script for deep muscle relaxation. Dis Nerv Sys 1977;38:703-8.

${ }^{51}$ Bernstein DA, Borkovec TD. Progressive relaxation training: a manual for the helping professions. Illinois: Research Press, 1973.

(Accepted 1 April 1982)

\title{
Evaluation of digitalis in cardiac failure
}

\author{
R G MURRAY, A C TWEDDEL, W MARTIN, D PEARSON, I HUTTON, T D V LAWRIE
}

\begin{abstract}
Ten patients in sinus rhythm with symptomatic cardiac failure participated in a study investigating the value of digitalis at rest and during dynamic exercise. A haemodynamic profile and left ventricular ejection fraction were measured before treatment, after intravenous ouabain, and after six weeks of maintenance treatment with digoxin.

There was no significant change in the haemodynamic profile or in the left ventricular ejection fraction at rest after either glycoside. During exercise there was a

University Department of Medical Cardiology and Department of Nuclear Medicine, Glasgow Royal Infirmary, Glasgow G4 OSF

R G MURRAY, MRCP, senior registrar (now senior research fellow, University Department of Cardiovascular Medicine, Queen Elizabeth Hospital, Birmingham B15)

A C TWEDDEL, MB, registrar

W MARTIN, PHD, senior physicist

D PEARSON, MRCP, registrar (now senior registrar in medicine, Postgraduate Medical Centre, Raigmore Hospital, Inverness)

I HUTTON, MD, senior lecture

T D V LAWRIE, MD, professor
\end{abstract}

significant reduction in left ventricular filling pressure from $393 \mathrm{~mm} \mathrm{Hg}$ to $34 \pm 3 \mathrm{~mm} \mathrm{Hg}(\mathrm{p}<0.05)$ after ouabain and to $33 \pm 3 \mathrm{~mm} \mathrm{Hg}(\mathrm{p}<0.02)$ after digoxin. Cardiac index improved from $3.310 .31 / \mathrm{min} / \mathrm{m}^{2}$ to $4.0+0.41 / \mathrm{min} / \mathrm{m}^{2}(\mathrm{p}<0.01)$ after ouabain and to $3 \cdot 8 \pm 0.4$ $1 / \mathbf{m i n} / \mathbf{m}^{2}(\mathbf{p}<0.01)$ after digoxin. During exercise stroke volume index and stroke work index also improved significantly with both glycosides. This was accompanied by an increase in left ventricular ejection fraction from $29+2 \%$ to $36 \pm 3 \%(p<0.05)$ after ouabain and digoxin.

In this study both intravenous ouabain and maintenance treatment with oral digoxin exerted a modest positive inotropic effect in patients with cardiac failure in sinus rhythm. The haemodynamic benefit, however, was manifest only during exertion.

\section{Introduction}

For many years digitalis preparations have been advocated as the principal positive inotropic agents for cardiac failure. Experiments showed a cardiotonic effect, while studies of acute administration confirmed improved myocardial performance. ${ }^{1-7}$ Nevertheless, the translation of these findings into clinical 
benefit in patients receiving maintenance treatment who remain in sinus rhythm has been more controversial. Some reports have suggested continued improvement, ${ }^{8-10}$ while other workers have been less impressed ${ }^{11}{ }^{12}$; and the ease with which maintenance treatment can be withdrawn without clinical deterioration has been noted. ${ }^{13-15}$ Thus the role of maintenance treatment with digitalis is still not clear. Moreover, the question of efficacy during exercise has seldom been examined. ${ }^{70}$

We describe the use of digitalis given acutely and as maintenance treatment in 10 patients with chronic cardiac failure. A haemodynamic profile and left ventricular ejection fraction were obtained at rest and during upright dynamic exercise before treatment, after intravenous ouabain, and after six weeks of oral digoxin.

\section{Patients and methods}

We studied nine men and one woman aged 42-65 years (mean 51) with class III or IV (NYHA) disability despite diuretics (thiazide in one case; frusemide in the remainder). In seven patients the cardiac failure was caused by coronary disease, and in three it was idiopathic; all were in normal sinus rhythm. None of the patients had been given digitalis before. All patients gave informed consent to the study.

Study design (fig 1)-Control haemodynamic data were obtained at rest and during upright dynamic exercise using a bicycle ergometer.

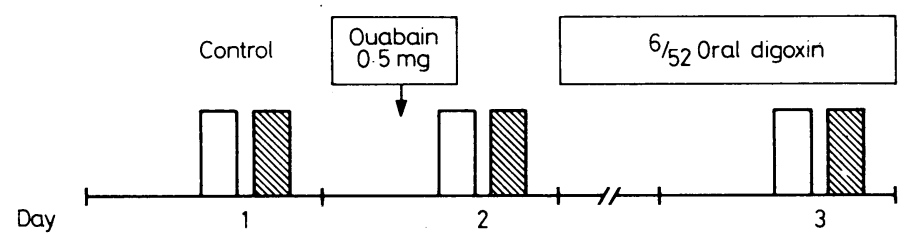

FIG 1-Study design. Haemodynamic data and left ventricular ejection fraction measured at rest (open columns) and during dynamic exercise (shaded columns) after intravenous ouabain and after six weeks' maintenance with oral digoxin.

The level of exercise achieved (25-75 watts) permitted three to five minutes of exercise and was identical for each patient at each phase of the study. Measurements were repeated at rest and during exercise 30-60 minutes after intravenous ouabain $(0.5 \mathrm{mg})$. Patients were then given oral digoxin for six weeks and the study repeated. The dose of digoxin was adjusted to maintain the plasma concentration within the therapeutic range $(1 \cdot 3-2 \cdot 6 \mathrm{nmol} / 1 ; 1 \cdot 0-2 \cdot 0 \mathrm{ng} / \mathrm{ml})$. Patients continued with their diuretic treatment throughout the study, but no other cardioactive drug was prescribed.

Haemodynamic measurements-Heart rate was measured from the electrocardiogram and arterial blood pressure by sphygmomanometer. A flow-directed thermodilution catheter was inserted to give pulmonary arterial and wedge pressures. Left ventricular filling pressure was accepted as mean pulmonary capillary wedge pressure or pulmonary artery diastolic pressure. Cardiac output was measured in triplicate by thermodilution. The following calculations were used: cardiac index (cardiac output/body surface area; $1 / \mathrm{min} / \mathrm{m}^{2}$ ); stroke volume index (cardiac index $/$ heart rate; $\mathrm{ml} / \mathrm{m}^{2}$ ); mean arterial pressure ((one-third pulse pressure) +diastolic pressure; $\mathrm{mm} \mathrm{Hg}$ ); left ventricular systolic mean pressure ((two-thirds pulse pressure) + diastolic pressure; $\mathrm{mm} \mathrm{Hg}$ ); left ventricular stroke work index (stroke volume index $\times$ (left ventricular systolic mean pressure-left ventricular filling pressure $\left.) \times 0.0136 ; \mathrm{g} \mathrm{m} / \mathrm{m}^{2}\right)$; total vascular resistance ((mean arterial pressure/cardiac output) $\times 80 ; \mathrm{dyn} / \mathrm{s} / \mathrm{cm}^{-5}$ ).

Radionuclide ventriculography-Radionuclide left ventriculography was performed after sequential in-vivo red-cell labelling with $20 \mathrm{mCi}$ $99^{\mathrm{m}}$ Tc Pyrolite. Equilibrium data were obtained in the modified left anterior oblique projection using an IGE Maxi Camera interfaced to a Varian $620 \mathrm{~L}$ computer. Data were acquired in list mode and 16 frames per cardiac cycle reconstructed using a $32 \times 32$ matrix with about 200000 counts per frame. Global left ventricular ejection fraction was calculated using a series of algorythms based on contouring validated in our laboratory. Left ventricular ejection fraction so calculated correlated closely with that obtained at contrast angiography $(r=0.90 ; n=63)$, is relatively free from observer variation, and is reproducible at rest and on exercise.
Statistical analysis was by Student's paired $t$ test. Differences were taken as significant at $\mathrm{p}<0 \cdot 05$. Results are expressed as means $\pm \mathrm{SEM}$.

\section{Results}

Resting haemodynamic data (table I)-Control left ventricular filling pressure was $19 \pm 2.6 \mathrm{~mm} \mathrm{Hg}$ and was not influenced by intravenous ouabain or oral digoxin. Cardiac index was $2 \cdot 0 \pm 0 \cdot 2$ $1 / \mathrm{min} / \mathrm{m}^{2}$ before treatment and was also unchanged by acute or maintenance digitalis treatment. The calculated measurements of stroke volume index, stroke work index, and systemic vascular resistance were unchanged, and left ventricular ejection fraction was $33+2 \cdot 7 \%$ during the control period, $32+2 \cdot 3 \%$ after ouabain, and $35+2.3 \%$ after digoxin. Thus the glycoside did not significantly alter the resting haemodynamic profile.

Exercise haemodynamic data (table II) were obtained in eight patients (two were unable to sustain exercise to permit data acquisition).

TABLE I-Resting haemodynamic data (values are means $\pm S E M$ )

\begin{tabular}{|c|c|c|c|c|}
\hline & & Control & Ouabain & Digoxin \\
\hline $\begin{array}{l}\text { Heart rate (beats } / \mathrm{min}) \quad \ldots \\
\text { Mean arterial pressure (mm } \mathrm{Hg}) \ldots \\
\text { Left ventricular filling pressure }(\mathrm{mm} \\
\text { Cardiac index }\left(1 / \mathrm{min} / \mathrm{m}^{2}\right) \ldots \\
\text { Stroke volume index }\left(\mathrm{ml}^{2} / b_{e a t} / \mathrm{m}^{2}\right) \\
\text { Total systemic resistance }\left(\mathrm{dyn} / \mathrm{s} / \mathrm{cm}^{-5}\right) \\
\text { Stroke work index }\left(\mathrm{g} \mathrm{m} / \mathrm{m}^{2}\right) \\
\text { Left ventricular ejection fraction }\left({ }_{0}\right)\end{array}$ & $\begin{array}{l}\ldots \\
\ddot{\mathrm{Hg}} \\
\cdots \\
\cdots \\
\cdots\end{array}$ & $\begin{array}{r}69+3 \cdot 6 \\
89+3 \cdot 1 \\
19+2 \cdot 6 \\
2 \cdot 0+0 \cdot 2 \\
29+3 \\
2080+200 \\
35+4 \cdot 2 \\
33+2 \cdot 7\end{array}$ & $\begin{aligned} 67 & \pm 2 \cdot 7 \\
88 & \pm 3 \cdot 5 \\
17 & \pm 1 \cdot 8 \\
2 \cdot 1 & \pm 0 \cdot 1 \\
32 & \pm 2 \\
1849 & \pm 84 \\
38 & \pm 3 \cdot 6 \\
32 & \pm 2 \cdot 3\end{aligned}$ & $\begin{aligned} & 67 \pm 2 \cdot 9 \\
& 91 \pm 3 \cdot 2 \\
& 18 \pm 1 \cdot 8 \\
& 2 \cdot 0 \pm 0 \cdot 1 \\
& 29 \pm 2 \\
& 2121 \pm 129 \\
& 35 \pm 3 \cdot 2 \\
& 35 \pm 2 \cdot 3\end{aligned}$ \\
\hline
\end{tabular}

TABLE II-Exercise haemodynamic data (values are means $\pm S E M$ )

\begin{tabular}{|c|c|c|c|}
\hline & Control & Ouabain & Digoxin \\
\hline 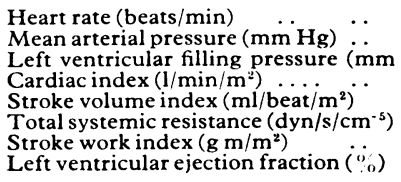 & 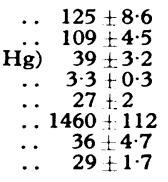 & $\begin{array}{c}120 \pm 7 \cdot 3 \\
111 \pm 3 \cdot 3 \\
34 \pm 2 \cdot 6^{*} \\
4 \cdot 0 \pm 0 \cdot 4^{* * *} \\
33 \pm 3^{* * * *} \\
1291 \pm 131 \\
47 \pm 5 \cdot 6^{* * *} \\
36 \pm 2 \cdot 9^{*}\end{array}$ & $\begin{aligned} & 122 \pm 4 \cdot 5 \\
& 120 \pm 8 \cdot 0 \\
& 33 \pm 3 \cdot 4^{* * *} \\
& 3 \cdot 8 \pm 0 \cdot 4^{* * * *} \\
& 31 \pm 3 * \\
& 1416 \pm 140 \\
& 49 \pm 8 \cdot 2^{* * *} \\
& 36 \pm 3 \cdot 1^{* *}\end{aligned}$ \\
\hline
\end{tabular}

Compared with control: ${ }^{*} \mathrm{p}<0.05 ;{ }^{* *} \mathrm{p}<0.02 ;{ }^{* * *} \mathrm{p}<0.01$

Heart rate and mean arterial pressure were unchanged by ouabain and digoxin. Left ventricular filling pressure fell significantly from $39+3.2 \mathrm{~mm} \mathrm{Hg}$ to $34+2.6 \mathrm{~mm} \mathrm{Hg}(13 \%)$ with ouabain and to $33+3.4 \mathrm{~mm} \mathrm{Hg}(15 \%)$ with digoxin. Cardiac index increased significantly from $3.3 \pm 0.31 / \mathrm{min} / \mathrm{m}^{2}$ to $4.0 \pm 0.41 / \mathrm{min} / \mathrm{m}^{2}(21 \%)$ after ouabain and to $3 \cdot 8 \pm 0.4 \mathrm{l} / \mathrm{min} / \mathrm{m}^{2}(15 \%)$ after digoxin. Stroke work index increased significantly from $36 \pm 4.7 \mathrm{~g} \mathrm{~m} / \mathrm{m}^{2}$ to $47 \pm 5.6$ $\mathrm{g} \mathrm{m} / \mathrm{m}^{2}(31 \%)$ with ouabain and to $49 \pm 8.2 \mathrm{~g} \mathrm{~m} / \mathrm{m}^{2}(36 \%)$ with digoxin. Figures 2 and 3 show the relation between change in left ventricular filling pressure and stroke work index in individual patients. An increase in stroke work index with a concomitant fall in left ventricular filling pressure during exercise indicating improved left ventricular performance occurred in six of the eight patients after both ouabain and digoxin. These changes were accompanied by a significant increase in ejection fraction from $29 \pm 1.7 \%$ to $36 \pm 2.9 \%$ with ouabain and to $36 \pm 3.1 \%$ with digoxin. Systemic vascular resistance was unchanged.

\section{Discussion}

Despite experiments on isolated heart muscle and intact hearts showing the inotropic effect of digitalis, the ability of glycosides to improve cardiac performance remains controversial. Our data suggest that digitalis may improve cardiac function but that this may be manifest only during dynamic exercise, an aspect of digitalis seldom mentioned. ${ }^{210}$ The haemodynamic response to treatment at rest was variable and no clear benefit could be detected, which agrees with other studies.11 1216 On exercise, however, left ventricular filling pressure fell, cardiac 
index increased, and stroke work index increased. These changes occurred after acute ouabain administration, were maintained with oral digoxin, and suggest an improvement in left ventricular function. This improvement was apparently mediated by improved contractility. Since systemic vascular resistance and arterial pressure were unchanged, alteration in impedence to left ventricular outflow was probably not responsible. Left ventricular filling pressure fell; hence it is unlikely that the increase in stroke volume was related to an increase in preload. Of the three determinants of stroke volume

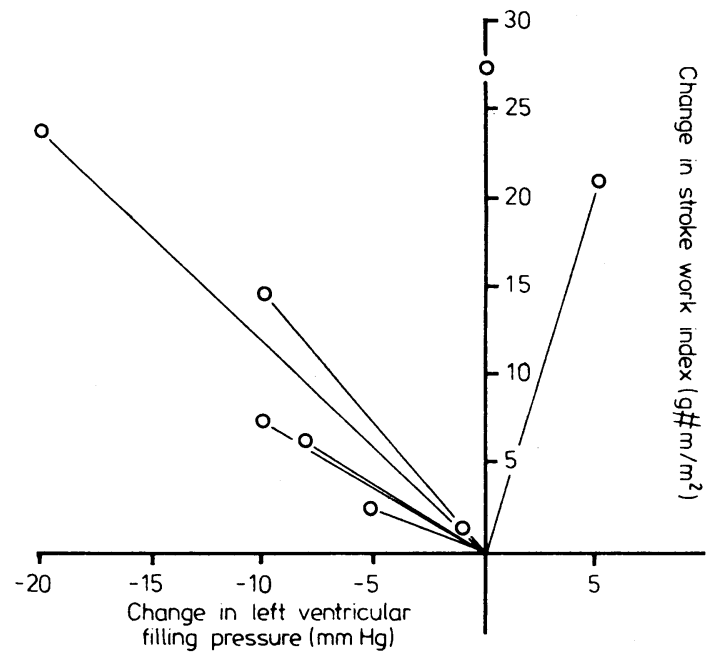

FIG 2-Comparison of changes in left ventricular filling pressure and stroke work index during exercise after intravenous ouabain. Concomitant fall in left ventricular filling pressure and increase in stroke work index indicating improved left ventricular performance occurred in six of eight patients.

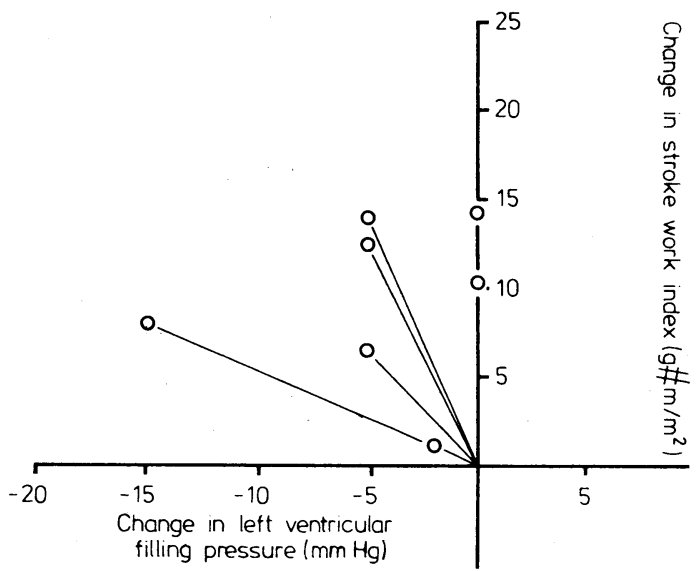

FIG 3-Comparison of changes in left ventricular filling pressure and stroke work index during exercise after maintenance with digoxin. Concomitant fall in left ventricular filling pressure and increase in stroke work index occurred in same six of eight patients as in fig 2 .

(impedence to left ventricular outflow, preload, and contractility), probably increased contractility was responsible for the observed increase in stroke volume. This is supported by the significant increase in left ventricular ejection fraction. The reduction in left ventricular filling pressure may also be explained by augmented stroke volume resulting in a reduction in left ventricular end-diastolic volume. Digitalis, however, may reduce venous tone, ${ }^{17}$ so that venous pooling may have been partly responsible.
Improved left ventricular performance did not occur in all patients: an increase in stroke work index with a concomitant fall in left ventricular filling pressure during exercise occurred in six of the eight patients (figs 2,3 ). This contrasts with the study of Arnold et al, ${ }^{10}$ in which the glycoside produced a uniform improvement in left ventricular function. In that study patients with class IV symptoms were excluded, possibly eliminating a group of patients who do not respond to digoxin.

There was also a discrepancy between subjective symptoms and haemodynamic profile, which has been noted before. ${ }^{18}$ Despite the overall improvement in haemodynamics during exercise there was no consistent improvement in symptoms, five patients having a reduction in effort dyspnoea and the remainder being unchanged.

Perhaps the strongest indictment of the failure of digoxin is the ease with which it can be withdrawn without clinical deterioration..$^{13-15}$ Nevertheless, the indications for long-term treatment in these heterogeneous populations were variable and in some may have been inappropriate. Some patients did indeed develop acute cardiac failure after digoxin withdrawal, while some required alteration in diuretic treatment.

Our purpose was to investigate the haemodynamic effect of introducing and maintaining glycoside treatment in patients with established left ventricular dysfunction. Although the number of patients studied was small and the results somewhat variable in individual patients, left ventricular performance improved in most during exertion. These results therefore suggest that in chronic cardiac failure digoxin is appropriate and should not be withheld.

\section{References}

1 Siegel JH, Sonnenblick EH. Isometric time tension relationship as an index of myocardial contractility. Circ Res 1963;12:597-610.

2 Wallace AG, Mitchell JH, Skinner MS, Sarnoff SJ. Duration of phases of left ventricular systole. Circ Res 1963;12:611-9.

${ }^{3}$ Smith TW, Haber E. Digitalis. N Engl $\mathcal{f}$ Med 1973;259:945-52, 1010-5, 1063-72, 1125-9.

${ }^{4}$ McMichael J, Sharpey-Schafer EP. The action of intravenous digoxin in man. $Q \mathcal{F}$ Med $1944 ; 13: 123-35$.

5 Bloomfield RA, Rapoport B, Milnor JP, Long WK, Mebane JG, Ellis LB. The effects of the cardiac glycoside upon the hemodynamics of the circulation in congestive heart failure. 1 Ouabain. $f$ Clin Invest 1948 ; 27 :588-99.

6 Harvey RM, Ferrer M, Cathcart RT, Richards DW, Cournand AS. Some effects of digoxin upon the heart and circulation in man : digoxin in left ventricular failure. Am F Med 1949;7:439-53.

7 Selzer A, Malmborg RO. Hemodynamic effects of digoxin in latent heart failure. Circulation $1962 ; 25: 695-702$.

${ }^{8}$ Dobbs SM, Kenyon WI, Dobbs RJ. Maintenance digoxin after an episode of heart failure : placebo controlled trial in outpatients. $\mathrm{Br} \mathrm{Med}$ f 1977; i :749-52.

- Fonrose HA, Ahlbaum N, Bugatch E, Cohen M, Genovese C, Kelly J. The efficacy of digitalis withdrawal in an institutional aged population. f Am Geriatr Soc 1974 ;22:208-11.

10 Arnold SB, Byrd RC, Meister W, et al. Long term digitalis therapy improves left ventricular function in heart failure. $N$ Engl $f \mathrm{Med}$ $1980 ; 303: 1443-8$

11 Davidson CD, Gibson D. Clinical significance of the positive inotropic action of digoxin in patients with left ventricular disease. $\mathrm{Br} \mathrm{Heart} \mathcal{F}$ $1973 ; 35: 970-6$.

12 Selzer A. Comparative studies of acute and chronic effects of digitalis in cardiac failure. Circulation 1960;22:807.

${ }^{13}$ Dall JLC. Maintenance digoxin in elderly patients. $\mathrm{Br}$ Med $\mathcal{f} 1970$;ii 705-7.

${ }^{14}$ Hull SM, Mackintosh A. Discontinuation of maintenance digoxin therapy in general practice. Lancet 1977 ; ii :1054-5.

15 Johnston GD, McDevitt DG. Is maintenance digoxin necessary in patients with sinus rhythm? Lancet $1979 ; \mathrm{i}: 567-70$.

16 Cohn V, Selzer A, Kersh E, Karpman LS, Goldschlager N. Variability of hemodynamic response to acute digitalisation in chronic cardiac failure due to cardiomyopathy and coronary artery disease. Am $\mathcal{f}$ Cardiol $1975 ; 35$ : $461-8$.

17 Mason DT, Braunwald E. Studies in digitalis. X: Effects of ouabain on forearm vascular resistance and venous tone in normal subjects and in patients with heart failure. $\mathcal{f}$ Clin Invest $1964 ; 43: 532-43$

18 Benge W, Litchfield RL, Marcus ML. Exercise capacity in patients with severe left ventricular dysfunction. Circulation 1980;61:955-9.

(Accepted 29 March 1982) 